Sains Malaysiana 49(2)(2020): 399-404

http://dx.doi.org/10.17576/jsm-2020-4902-18

\title{
Clinical Significance of Blood Supply of the Fornix of Brain: A Cadaveric Study
}

(Keertian Klinikal Pembekuan Darah Forniks Otak: Suatu Kajian Kadaverik)

\author{
PATChARAPORn SRISAiKAEW, TANAT VANIYAPONG, SRIJit DAS \& PASUK MAHHAKRANUKRAUH*
}

\begin{abstract}
Transient ischemic attack (TIA) of the fornix causes a spectrum of memory deficits, which increases the contributions of vascular disease to dementia which is known as early-onset dementia. As the fornix, the white matter bundle, serves as the major efferent pathway connecting the hippocampus with other human limbic structures, a variety of lesions that damage the fornix could lead to significant memory impairment. Therefore, the blood supply of fornix is a concern. This study aims to study the arterial supply of fornix. Thirty fresh human cadaveric heads were used. They were preserved by the mixture of fixation solution for fornix anatomical dissection and injected with coloured latex solution for visualization of cerebral vasculature through 6 critical steps of approaches. The result showed that the fimbriae of fornix were mainly supplied by the branches of posterior cerebral artery (PCA) and two cases were found to have the anastomoses of those branches with the choroidal artery (ChA). The proposed technique confirmed the ability of coloration of human cerebral vasculature by using colored latex solution which penetrated into cerebral small vessels leading to a precise understanding of the arterial supply of fornix in human brain which is essential for neurosurgeon, neurosurgical training and researchers.
\end{abstract}

Keywords: Arteries; brain; fixation; fornix; latex injection

ABSTRAK

Serangan iskemik sementara (TIA) di fornix menyebabkan pelbagai spektrum defisit memori yang secara langsung meningkatkan sumbangan penyakit vaskular kepada demensia yang juga dikenali sebagai demensia permulaan-awal. Oleh kerana fornix terdiri daripada kumpulan jirim putih yang berfungsi sebagai laluan eferen utama yang menghubungkan hipokampus dengan struktur limbik manusia yang lain, kecederaan yang merosakkan fornix boleh mengakibatkan kerosotan memori yang ketara. Oleh itu, bekalan darah fornix menjadi kebimbangan. Tujuan penyelidikan ini adalah untuk mengkaji bekalan saluran darah arteri fornix. Tiga puluh kepala daripada kadaver yang segar telah digunakan. Setiap kepala diawetkan dengan campuran cecair fiksasi untuk pembedahan anatomi fornix dan disuntik dengan larutan lateks berwarna untuk memvisualisasikan vaskular serebrum melalui pendekatan 6 langkah yang kritikal. Hasil kajian ini menunjukkan bahawa fimbria fornix kebanyakannya dibekalkan oleh rangkaian arteri serebral posterior (PCA) dan terdapat dua kes dengan penyambungan cabang arteri ini bersama dengan arteri koroid (ChA) dijumpai. Teknik yang dikemukakan ini mengesahkan keupayaan pewarnaan vaskular serebrum manusia dengan menggunakan larutan lateks berwarna yang boleh menembusi salur darah kecil serebral dan membawa kepada pemahaman yang terperinci terhadap bekalan saluran darah arteri fornix di dalam otak manusia yang terbukti penting untuk pakar bedah saraf, latihan bedah saraf dan untuk para penyelidik.

Kata kunci: Arteri; fiksasi; fornix; otak; suntikan lateks

\section{INTRODUCTION}

As the global population is aging in this twenty-first century, health problems also increase. The incidence of dementia patients arose from 48.6 million in 2015 to 75 million in 2030, and it is expected to increase to 131 million by 2050 (Prince 2015). The prevalence of dementia or neurodegenerative disorders (NCD) is on the rise due to the expansions of lifespans. It is incurable together with many conditions resulting in progressive degeneration and ending up with the death of nerve cells. The NCD group is characterized by a progressive decline of at least one or more cognitive functions including complex attention, learning and memory, executive function, language, social cognition, and perceptual-motor function. There are many causes that could lead to developing NCD such as brain cell death, head injury, brain tumor, cerebrovascular diseases i.e. stroke, human immunodeficiency virus (HIV) infection and reversible causes such as vitamin deficiency and thyroid abnormalities.

Cerebrovascular disease is the most prevalent pathology among dementia patients which generally leads to a decline in cognitive function, short-term memory (STM) and thinking abilities.The blockage (ischemic stroke), leakage (hemorrhagic stroke) and temporarily blocks of blood flow to the brain is called a mini-stroke or transient ischemic attack (TIA), is the main causes of the 
vascular dementia (VaD) or vascular cognitive impairment (VCI) or vascular neurocognitive disorder (vascular NCD), which is the second most common cause of the NCD $(15 \%$ to $20 \%$ of all dementia cases) after Alzheimer's disease, $\mathrm{AD}(60 \%$ to $70 \%$ of all dementia cases) (Association American Psychiatrist 2013; Roher et al. 2012).

Previous research showed that TIAs happened a year before the patient was diagnosed with cognitive impairment and the severity of white matter changes (WMCs). Furthermore, the medial temporal lobe atrophy (MTLA) patients could develop to early-onset dementia within six months. Moreover, they stated that the people who had TIA/strokes episode had a higher risk of developing early onset-dementia than those with no history of TIA and/or strokes (Mok et al. 2016; Yang et al. 2015).

The fornix is a white matter (WM) bundle within the limbic system which plays an important role in human memory circuits, called the Papez circuit. In recent years, the fornix is a key structure in many types of research as a biomarker for diagnosis, progression and treatment in mild-NCD and major-NCD along with the lack of knowledge of its arterial supply. Moreover, several research studies reported a variety of fornix lesions e.g. insufficient blood supply and/or infarction causing a spectrum of memory deficits (D' Esposito et al. 1995; Moudgil et al. 2000; Yasuno et al. 1999). Hence, due to the lack of effective treatment for NCD, the early detection of the NCD due to cerebrovascular diseases and its association with the fornix must be of concern.

Ultimately, in neurosurgical training and research, it is very important to have an accurate understanding of cerebral blood vessel anatomy and its supply. Therefore, the authors need to explore the link between cerebral blood supply of the crucial WM bundle called fornix and its impact on clinical significance. The purpose of this study was to find the arterial supply of the fornix of the human brain in fresh cadavers by using fixation, coloration, and dissection methods.

\section{MATERIALS AND METHODS}

This study was approved by the Ethics Committee of the Faculty of Medicine, Chiang Mai University; Research ID: ANA-2561-05620.

Thirty fresh cadaveric heads (14 females and 16 males), ages between 28-91 years (average age of 67.5 years old), were obtained from the Department of Anatomy, Faculty of Medicine, Chiang Mai University and preserved with fixation solution for injection of colored latex solution and anatomical dissection. All experiments were held at the Cadaveric Surgical Training Center, Department of Anatomy, Faculty of Medicine, Chiang Mai University, Chiang Mai, Thailand in order to study the coloration technique and the anatomical and arterial supply of the fornix of the brain.

\section{COLORED LATEX SOLUTIONS}

Red latex solutions were obtained from Ward's Natural Science, Rochester, New York (latex injection medium, red, Lab Grade, 1-L bottle [LOT AD-18040-1].

\section{CRITICAL STEPS OF APPROACH}

Six steps were used to approach the vasculature system of the brain based on the modification of an earlier method (Alvernia et al. 2010). The steps were as follows:

\section{Cannulation of the cervical arteries and veins}

Dissection was performed to isolate the cervical vessels from the surrounding tissue. Cervical vessels were identified and cannulated including right and left common carotid arteries (CCAs), right and left vertebral arteries (VAs), and right and left internal jugular veins (IJVs), respectively.

\section{Irrigation of the arterial and venous systems}

The mixture of tap water dilution with $40 \%$ formaldehyde and $95 \%$ ethanol was used to remove clots and debris by using syringes for CCAs, IVs and IJVs. During irrigation, it was made sure that the flow from the contralateral and ipsilateral sides was present due to the anatomical configuration of the Circle of Willis and irrigation was continued until the water flow was clear.

\section{Formaldehyde and alcohol fixation}

Following the irrigation, a mixture of $40 \%$ formaldehyde and $10 \%$ ethanol was injected into the cannulated arteries and veins. Then, all vessels were closed to maintain the fixation solution within the vessels for 48 $\mathrm{h}$ in a container that contains $10 \%$ formaldehyde, $10 \%$ ethanol, and tap water and was kept refrigerated at 2 to $-4^{\circ} \mathrm{C}$.

\section{Colored latex injection of the arterial systems}

After two days, the red latex solution was first injected into CCAs and VAs then, left to dry for three to four hours. Once the latex was injected in the right-side vessel, the outflow would be in the contralateral side which was the left-side vessel because of the anatomical configuration of the circle of Willis. After three to four hours of air drying, the dry rubber of liquid latex solutions was formed.

\section{Post-injection preservation}

After the injection was finished, cadaveric heads were kept in the closed container that contained $10 \%$ formaldehyde, $10 \%$ ethanol, and tap water and kept refrigerated at 2 to $-4^{\circ} \mathrm{C}$ for few weeks. 


\section{Anatomical dissection}

The dissection began a month after the latex injection. The vessels were now full form, robust, and could withstand dissection. The order of dissection was as follows: firstly, the scalp and both sides of temporalis muscles were cut and detached from their origin. Then, the calvaria was cut by a saw and removed first to view the internal features of the cranial cavity. Secondly, a longitudinal incision of dura matter was made following the line of the saw cut. The cerebral falx (falx cerebri) was cut and carefully removed with a blade from its attachment including anterior attachment at the crista galli and the posterior attachment at the cerebellar tentorium. Thirdly, the brain was gently removed by cutting all the attachments including the left and right side of internal carotid artery (ICA), basilar artery (BA), the brain stem, cerebellar tentorium (tentorium cerebelli) and cerebellar falx (falx cerebelli). Ultimately, the WM dissection proceeded from the inferior surface of the brain. We identified the cerebral blood vessels at the base of the brain which comprise the following: VAs, ICAs, posterior inferior cerebellar arteries (PICAs), BA and pontine branches, anterior inferior cerebellar arteries (AICAs), superior cerebellar arteries (SCAs), posterior cerebral arteries (PCAs), posterior communicating arteries (PCoAs), ophthalmic arteries (OA), middle cerebral arteries (MCAs), anterior cerebral arteries (ACAs) and anterior communicating artery (ACoA).

\section{RESULTS AND DISCUSSION}

The fornix plays an important role in human memory by connecting the hippocampus with other limbic structures. It is a fundamental structure in the Papez circuit, which is a closed neural circuitry that starts and ends in the hippocampus (Papez 1937; Thomas et al. 2011). Several types of research showed that a variety of lesions that damage the fornix could lead to significant memory impairment and fulfill the NCD criteria.

Figure 1 shows the colored Circle of Willis from the inferior view of the brain with a $60 \mathrm{X}$ magnification microscope. Moreover, a case of right fetal-type PCoA was found counting as $9.1 \%$ of all 11 cases. It was a common incidental finding where the PCoA was larger than the P1 segment of PCA. The importance of this condition is the effect in vascular intervention procedures such as the coiling of a PCoA aneurysm. In addition, the colored latex solution clearly penetrated the cerebral small vessels as shown in Figure 1.

The fimbriae were the beginning part of fornix which began on both sides of the hippocampus, with a rich blood supply mainly from the branches of PCA as shown in Figure 2. Figure 3 shows the anastomoses of posterior choroidal arteries (PChA) which were the central branch of the P2 segment of the PCA and ChA supplying the crura and the body of the fornix, occurring in two of 11 cases counting as $18.2 \%$.

There is a consensus that dementia is emerging among multiple age-related neurodegenerative factors and vascular associated pathologies. A healthy cardiovascular system is essential for brain function and living survival. Researches showed that total cerebral blood flow of AD was $20 \%$ lower than healthy controls, which means a reduction in cerebral perfusion, and also correlated with a reduction in pulse pressure and cognitive measurements (Roher et al. 2012). Interestingly, patients with lower total brain perfusion had significantly more white matter lesions

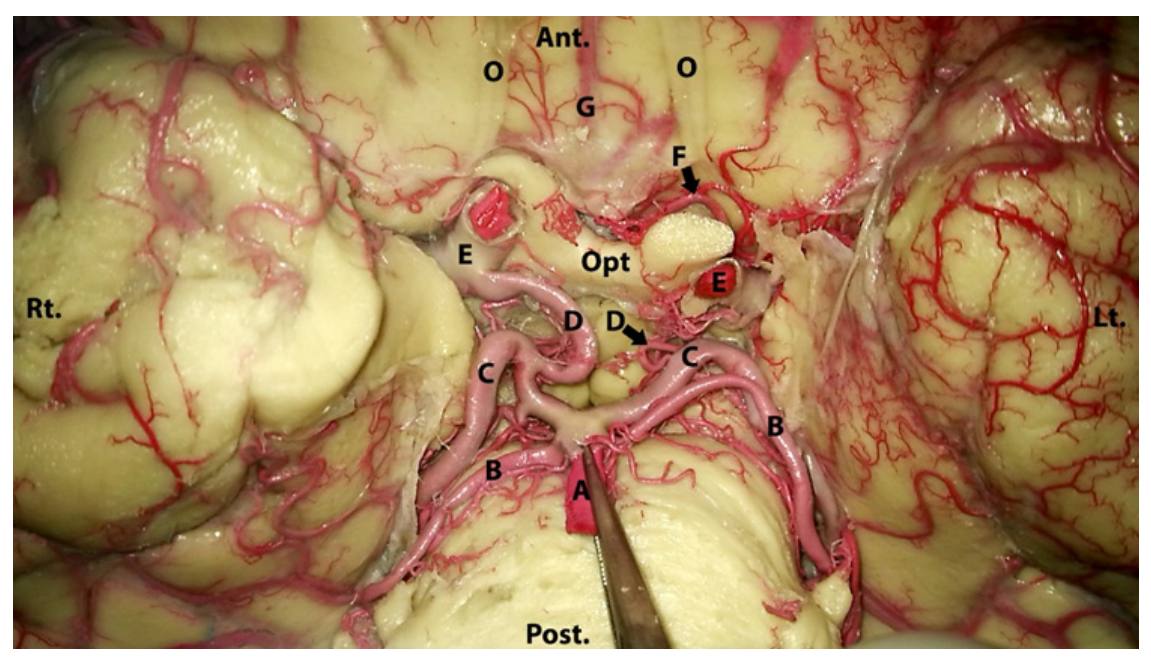

FIGURE 1. Inferior view of the brain showing the color of Circle of Willis with $60 \times$ magnification microscope. A forceps was holding a BA which gave branches of left and right SCA and continued to arise left and right PCA. A large PCoA was shown on the right side called fetal-type PCoA and the left PCoA is on a normal side. The ICA was cut during removing step of the brain and in the middle between left and right ICA, the optic chiasma was preserved. The ACAs and ACoA were partly covered by arachnoid matter. A: basilar artery (BA), B: superior cerebellar artery (SCA), C: posterior cerebral artery (PCA), D: posterior communicating artery (PCoA), E: internal carotid arteries (ICA), F: anterior cerebral artery (ACA), G: anterior communicating artery (ACoA), O; optic nerve, and Opt: optic chiasma. Abbreviation; Anterior (Ant.), Posterior (Post.), Right (Rt.), and Left (Lt.) 


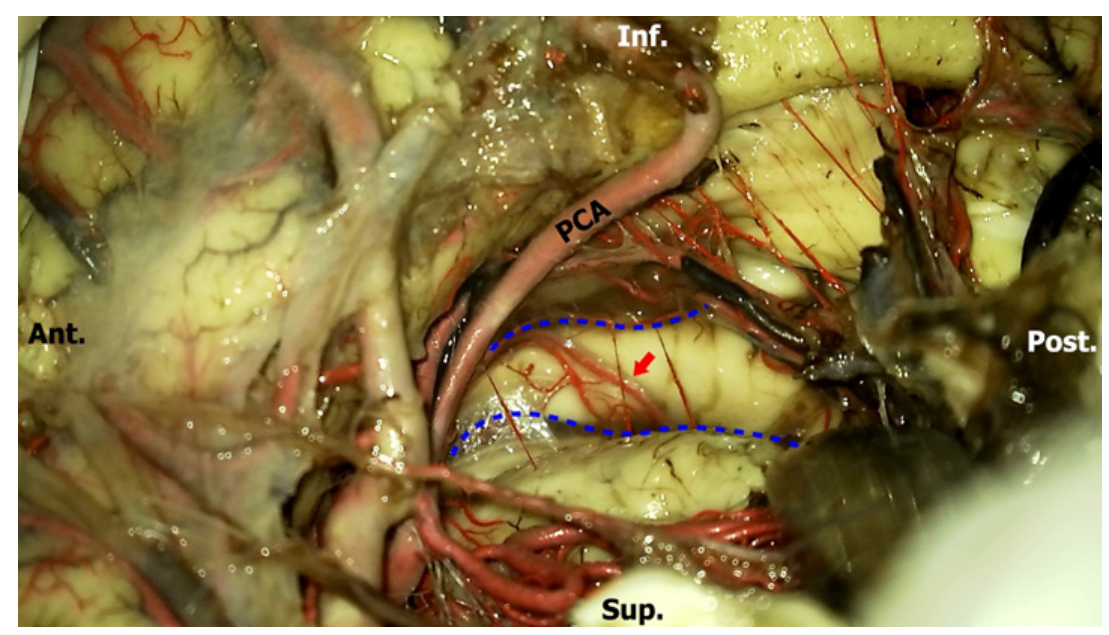

FIGURE 2. The $400 \times$ magnification microscope of the medial aspect of left cerebral hemisphere showed the fimbria of fornix was richly supplied by coloring branches of PCA (red arrow). Note: the blue dash line represents the border of left fimbria of fornix. PCA; posterior cerebral artery. Abbreviation; Anterior (Ant.), Posterior (Post.), Inferior (Inf.), and Superior (Sup.)

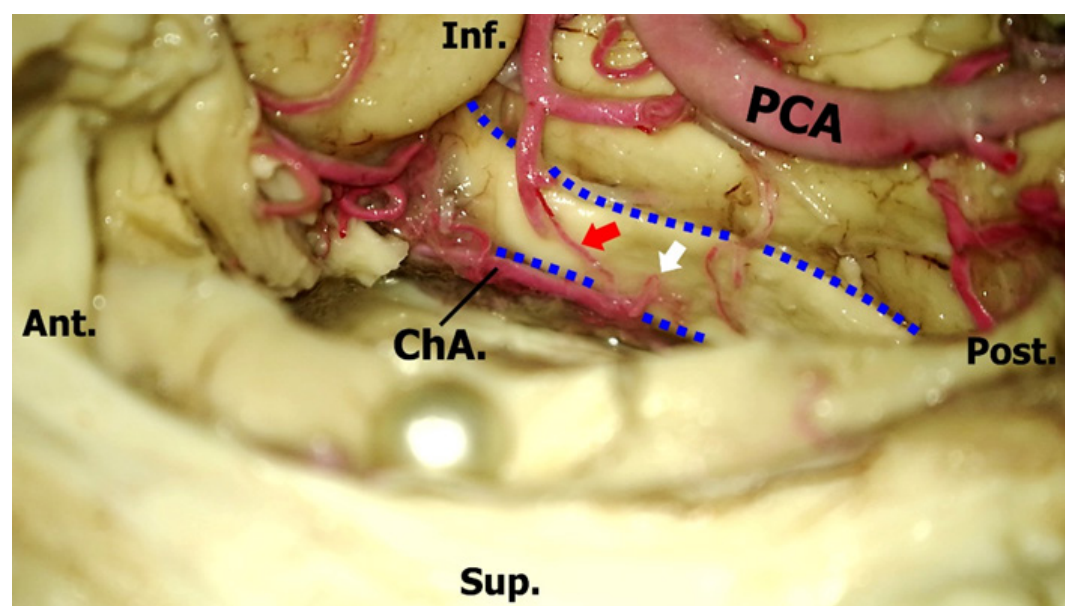

FIGURE 3. The $400 \times$ magnification microscope of the medial aspect of the right cerebral hemisphere showed another case of the coloring anastomoses of branches of PCA (red arrow) and branches of the ChA (white arrow) supplying the right crus of fornix. Note: the blue dash line represents the border of right crus of fornix. PCA; posterior cerebral artery, ChA; Choroidal artery. Abbreviation; Anterior (Ant.), Posterior (Post.), Inferior (Inf.), and Superior (Sup.)

(WML) than patients with higher brain perfusion (Vernooij et al. 2008).

Many techniques have been developed to study human cerebral blood vessels such as radiopaque substances injection (Kaplan 1953), tinted polyester resin (Gomes et al.1986), formaldehyde embalmed (Gunnal et al. 2013), cryo-preserved (Benet et al. 2014), colored silicone materials (Urgun et al. 2016), and colored latex solution (Alvernia et al. 2010). In 2010, Alvernia et al. found superior advantages of color latex solution over other methods. They stated that colored latex solution is already in a ready-to-use form, thus easy to prepare and deliver to cerebral small vessels resulting in a better understanding of the vascularization of the human brain and cerebral vasculature. Therefore, we decided to modify our methods based on their findings.
In the present study, we showed a new method of using fixation and colored latex coloration in order to find the arterial supply of the fornix by using fresh cadaveric brains. We found that formaldehyde solution provided excellent results in the fixation method as brains were maintained in the initial condition, no changes were noticed, and the brains were stiff enough to perform WM dissection. Furthermore, with the coloration method, latex solution could render the visualization of the precise branches of the vasculature by deeper penetration of the cerebral small vessels. Eleven injected cadaveric head showed outstanding color and 14 heads had suboptimal results. Five specimens were excluded due to the autolysis of the brain before proceeding. Latex solutions were very simple to prepare and were suitable for studying WM dissection in cadaveric heads. 
We are confirmed the abilities of formaldehyde solution and latex solution that provides an outstanding result of WM dissection and the study of cerebral blood vessels. Certainly, the color injection of the cerebral vasculature is very commonly used to improve the quality of anatomic detail, especially for neurosurgical training and research. In the dissection method, due to the specific anatomical of the fornix, which is situated on the medial aspect of the cerebral hemisphere and its body suspended beneath the corpus callosum via the septum pellucidum, knowledge of the appropriate precise approach to the fornix without destroying surrounding structures is essential and must be of concern.

In this study, the researchers found that the most effective way to approach this key structure is a mediolateral dissection with the inferior view of the human brain. This idea was supported by several research studies in the past few years in which the mediolateral dissection procedures were more distinctive than the lateromedial dissection and can show most of the limbic structures better than another approach (Koutsarnakis et al. 2015; Pascalau et al. 2018). Ultimately, it is important to understand the WM fiber dissection because this method provides the neuroanatomical knowledge for surgical practice and research and its findings can be used in the clinical practices.

As a result, the new finding in this study was the beginning part of the fornix called 'fimbria' has a rich arterial supply from the PChA and there were some anastomoses of those branches and the choroidal arterial network (ChA) supplying the crus and body of the fornix. In the same way with the study of Mugikura and Takahashi (2015), they reported that the bilateral infarction of fornix was caused by the embolism of VA which migrated to PChA via the PCA. Therefore, this confirmed that the arterial supply of fornix can arise from the posterior circulation which is a mirror result of the present study. Likewise, the unilateral infarction of fornix has reported in several previous studies that it could lead to the cognitive decline and transient global amnesia (TGA) by Gupta et al. (2015).

Korematsu et al. (2010) also show that a small unilateral infarction at the column of fornix that could lead to memory impairment i.e. sudden anterograde and retrograde amnesia without any focal neurological lesion. It was confirmed by the neuropsychological test that it marked a decline in delayed recall, attention and concentration. In addition, several types of research (Meila et al. 2015; Mugikura \& Takahashi 2015b) were also concerned that the column of the fornix, which is a part of the Papez circuit, has strong relevance in postoperative amnesia. Moreover, Meila et al. (2015) also stated that SCA strokes could later lead to the infarction of the fornix and the damages of anterior columns of the fornix and the genus of the corpus callosum thereby leading to the trouble of STM and cognitive changes. According to the anatomical localization and features of the fornix, Ren et al. (2018) also mentioned that a small acute infarction of the column of fornix was easy to miss during the clinical examination. In addition, our findings can be used to predict neurological diseases i.e. development of early-onset dementia mainly due to vascular dementia. Hence, the histology of the fornix should further investigate the WM tissue characteristics at the microscopic level to confirm a precise understanding of the arterial supply of the fornix and its associated link with dementia.

\section{CONCLUSION}

The fornix receives a rich blood supply from branches from PCA. These finding provides a superior result of cerebral vessels anatomical knowledge to all researchers due to the lack of knowledge of the arterial supply of fornix and arises the benefit directly to the patients and neurosurgeon. The evidence in this study supports the use of formaldehyde solution, colored-latex solution and the mediolateral of WM dissection in fixation, coloration, and dissection methods, respectively. Meanwhile, it is essential to manifesting early diagnosis and treatment for these patients who endure memory disorders.

\section{ACKNOWLEDGEMENTS}

This research was supported by The Royal Golden Jubilee (RGJ) Ph.D. Programme and Faculty of Medicine Research Fund, Chiang Mai University, Chiang Mai, Thailand and partially supported by Chiang Mai University. The authors would like to thank the ZEISS Company for supporting the ZEISS OPMI Pico-surgical microscope, and the authors sincerely thank Pagorn Navic, a Ph.D. Candidate in Anatomy for assisting with the preparation of the fresh cadavers. The authors have no personal financial or institutional interest in any of the materials or devices in this article.

\section{REFERENCES}

Alvernia, J.E., Pradilla, G., Mertens, P., Lanzino, G. \& Rafael, J.T. 2010. Latex injection of cadaver heads. Operative Neurosurgery 67(2): 362-367.

Association American Psychiatric. 2013. Diagnostic and Statistical Manual of Mental Disorders (DSM-5®): American Psychiatric Pub.

Benet, A., Rincon-Torroella, J., Lawton, M.T. \& Sánchez, J.J.G. 2014. Novel embalming solution for neurosurgical simulation in cadavers. Journal of Neurosurgery 120(5): 1229-1237.

D’Esposito, M., Verfaellie, M., Alexander, M.P. \& Katz, D.I. 1995. Amnesia following traumatic bilateral fornix transection. Neurology 45(8): 1546-1550.

Gomes, F.B., Dujovny, M., Umansky, F., Berman, S.K., Diaz, F.G., Ausman, J.I., Mirchandani, H.G. \& Ray, W.J. 1986. Microanatomy of the anterior cerebral artery. Surgical Neurology 26(2): 129-141.

Gunnal, S.A., Wabale, R.N. \& Farooqui, M.S. 2013. Variations of anterior cerebral artery in human cadavers. Neurology Asia 18(3): 249-259.

Gupta, M., Kantor, M.A., Tung, C.E., Zhang, N. \& Albers, G.W. 2015. Transient global amnesia associated with a unilateral 
infarction of the fornix: Case report and review of the literature. Frontiers in Neurology 5: 291.

Kaplan, H.A. 1953. A technique for anatomical study of the blood vessels of the brain. The Anatomical Record 116(4): 507-510.

Korematsu, K., Hori, T., Morioka, M. \& Kuratsu, J.I. 2010. Memory impairment due to a small unilateral infarction of the fornix. Clinical Neurology and Neurosurgery 112(2): 164-166.

Koutsarnakis, C., Liakos, F., Kalyvas, A.V., Sakas, D.E. \& Stranjalis, G. 2015. A laboratory manual for stepwise cerebral white matter fiber dissection. World Neurosurgery 84(2): 483-493.

Meila, D., Saliou, G. \& Krings, T. 2015. Subcallosal artery stroke: Infarction of the fornix and the genu of the corpus callosum. The importance of the anterior communicating artery complex. Case series and review of the literature. Neuroradiology 57(1): 41-47.

Mok, V.C.T., Lam, B.Y.K., Wang, Z., Liu, W., Lisa, A., Leung, E.Y.L., Chen, S., Yang, J., Chu, W.C.W. \& Lau, A.Y.L. 2016. Delayed-onset dementia after stroke or transient ischemic attack. Alzheimer's \& Dementia 12(11): 1167-1176.

Moudgil, S.S., Azzouz, M., Al-Azzaz, A., Haut, M. \& Gutmann, L. 2000. Amnesia due to fornix infarction. Stroke 31(6): 1418-1419.

Mugikura, S. \& Takahashi, S. 2015a. Fornix infarction due to involvement of posterior circulation. Journal of Stroke and Cerebrovascular Diseases 24(12): 2883-2885.

Mugikura, S. \& Takahashi, S. 2015b. Infarction in the pars libera of the column of fornix including pre (cholinergic)and post (circuit of Papez fiber tracts)-commissural fibers causes 'basal forebrain' amnesia. Neuroradiology 57(7): 757-759.

Papez, J.W. 1937. A proposed mechanism of emotion. Archives of Neurology \& Psychiatry 38(4): 725-743.

Pascalau, R., Stănilă, R.P., Sfrângeu, S. \& Szabo, B. 2018. Anatomy of the limbic white matter tracts as revealed by fiber dissection and tractography. World Neurosurgery 113: 672-689.

Prince, M.J. 2015. World Alzheimer Report 2015: The Global Impact of Dementia: An Analysis of Prevalence, Incidence, Cost, and Trends. London: Alzheimer's Disease International.

Ren, C., Yuan, J., Tong, S., Xue, Y., Wu, H., Li, W., Wang, J., Sun, Z., Gong, L. \& Wang, X. 2018. Memory impairment due to a small acute infarction of the columns of the fornix. Journal of Stroke and Cerebrovascular Diseases 27(7): 138-143.

Roher, A.E., Debbins, J.P., Malek-Ahmadi, M., Chen, K., Pipe, J.G., Maze, S., Belden, C., Maarouf, C.L., Thiyyagura, P. \& Mo, H. 2012. Cerebral blood flow in Alzheimer's disease. Vascular Health and Risk Management 8: 599-611.

Thomas, A.G., Koumellis, P. \& Dineen, R.A. 2011. The fornix in health and disease: An imaging review. Radiographics 31(4): 1107-1121.

Urgun, K., Toktas, Z.O., Akakin, A., Yilmaz, B., Sahin, S. \& Kilic, T. 2016. A very quickly prepared, colored silicone material for injecting into cerebral vasculature for anatomical dissection: A novel and suitable material for both fresh and non-fresh cadavers. Turk. Neurosurg. 26(4): 568-573.

Vernooij, M.W., Van der Lugt, A., Ikram, M.A., Wielopolski, P.A., Vrooman, H.A., Hofman, A., Krestin, G.P. \& Breteler,
M.M.B. 2008. Total cerebral blood flow and total brain perfusion in the general population: The Rotterdam scan study. Journal of Cerebral Blood Flow \& Metabolism 28(2): 412-419.

Yang, J., Wong, A., Wang, Z., Liu, W., Au, L., Xiong, Y., Chu, W.W.C., Leung, E.Y.L., Chen, S. \& Lau, C. 2015. Risk factors for incident dementia after stroke and transient ischemic attack. Alzheimer's \& Dementia: The Journal of the Alzheimer's Association 11(1): 16-23.

Yasuno, F., Hirata, M., Takimoto, H., Taniguchi, M., Nakagawa, Y., Ikejiri, Y., Nishikawa, T., Shinozaki, K., Tanabe, H. \& Sugita, Y. 1999. Retrograde temporal order amnesia resulting from damage to the fornix. Journal of Neurology, Neurosurgery \& Psychiatry 67(1): 102-105.

Patcharaporn Srisaikaew \& Pasuk Mahhakranukrauh* $\mathrm{PhD}$ Degree Program in Anatomy

Faculty of Medicine

Chiang Mai University

Chiang Mai, 52000

Thailand

Patcharaporn Srisaikaew

Department of Anatomy

Faculty of Medicine

Chiang Mai University

Chiang Mai, 52000

Thailand

Tanat Vaniyapong

Division of Neurosurgery

Department of Surgery

Faculty of Medicine

Chiang Mai University

Chiang Mai, 52000

Thailand

Srijit Das

Department of Anatomy

Universiti Kebangsaan Malaysia Medical Centre

Jalan Yaacob Latif, Bandar Tun Razak

56000 Kuala Lumpur, Federal Territory

Malaysia

Pasuk Mahhakranukrauh*

Forensic Osteology Research Center

Faculty of Medicine

Chiang Mai University

Chiang Mai, 50200

Thailand

Pasuk Mahhakranukrauh*

Research Cluster in Osteology Research and Training Center (ORTC)

Chiang Mai University

Chiang Mai, 50200

Thailand

*Corresponding author; email: pasuk034@gmail.com

Received: 21 September 2019

Accepted: 5 November 2019 